\title{
Front Matter: Volume 7892
}

, "Front Matter: Volume 7892," Proc. SPIE 7892, Multimodal Biomedical Imaging VI, 789201 (23 March 2011); doi: 10.1117/12.891038

SPIE. Event: SPIE BiOS, 2011, San Francisco, California, United States 


\section{PROGRESS IN BIOMEDICAL OPTICS AND IMAGING}

Vol. 12, No. 10

\section{Multimodal Biomedical Imaging VI}

Fred S. Azar

Xavier Intes

Editors

22-23 January 2011

San Francisco, California, United States

Sponsored and Published by

SPIE

Volume 7892

Proceedings of SPIE, 1605-7422, v. 7892

SPIE is an international society advancing an interdisciplinary approach to the science and application of light. 
The papers included in this volume were part of the technical conference cited on the cover and title page. Papers were selected and subject to review by the editors and conference program committee. Some conference presentations may not be available for publication. The papers published in these proceedings reflect the work and thoughts of the authors and are published herein as submitted. The publisher is not responsible for the validity of the information or for any outcomes resulting from reliance thereon.

Please use the following format to cite material from this book:

Author(s), "Title of Paper," in Multimodal Biomedical Imaging VI, edited by Fred S. Azar, Xavier Intes, Proceedings of SPIE Vol. 7892 (SPIE, Bellingham, WA, 2011) Article CID Number.

ISSN $1605-7422$

ISBN 9780819484291

Published by

SPIE

P.O. Box 10, Bellingham, Washington 98227-0010 USA

Telephone +1 3606763290 (Pacific Time) · Fax +1 3606471445

SPIE.org

Copyright @ 2011 , Society of Photo-Optical Instrumentation Engineers.

Copying of material in this book for internal or personal use, or for the internal or personal use of specific clients, beyond the fair use provisions granted by the U.S. Copyright Law is authorized by SPIE subject to payment of copying fees. The Transactional Reporting Service base fee for this volume is $\$ 18.00$ per article (or portion thereof), which should be paid directly to the Copyright Clearance Center (CCC), 222 Rosewood Drive, Danvers, MA 01923. Payment may also be made electronically through CCC Online at copyright.com. Other copying for republication, resale, advertising or promotion, or any form of systematic or multiple reproduction of any material in this book is prohibited except with permission in writing from the publisher. The CCC fee code is 1605$7422 / 11 / \$ 18.00$.

Printed in the United States of America.

Publication of record for individual papers is online in the SPIE Digital Library.

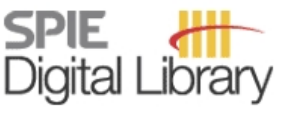

SPIEDigitalLibrary.org

Paper Numbering: Proceedings of SPIE follow an e-First publication model, with papers published first online and then in print and on CD-ROM. Papers are published as they are submitted and meet publication criteria. A unique, consistent, permanent citation identifier (CID) number is assigned to each article at the time of the first publication. Utilization of CIDs allows articles to be fully citable as soon as they are published online, and connects the same identifier to all online, print, and electronic versions of the publication. SPIE uses a six-digit CID article numbering system in which:

- The first four digits correspond to the SPIE volume number.

- The last two digits indicate publication order within the volume using a Base 36 numbering system employing both numerals and letters. These two-number sets start with 00, 01, 02, 03, 04 , 05, 06, 07, 08, 09, 0A, OB ... 0Z, followed by 10-1Z, 20-2Z, etc.

The CID number appears on each page of the manuscript. The complete citation is used on the first page, and an abbreviated version on subsequent pages. Numbers in the index correspond to the last two digits of the six-digit CID number. 


\section{Contents}

vii Conference Committee

ix Introduction

SESSION 1 FUNCTIONAL DIFUSE OPTICALIMAGING

789203 Evaluation of the acc uracy of brain optical properties estimation at different ages using the frequency-domain multi-distance method [7892-02]

M. Dehaes, Children's Hospital Boston (United States) and Harvard Medical School (United States); P. E. Grant, Children's Hospital Boston (United States), Harvard Medical School (United States) and Massachusetts General Hospital (United States); D. D. Sliva, Children's Hospital Boston (United States) and Harvard Medical School (United States);

N. Roche-Labarbe, Massachusetts General Hospital (United States) and Harvard Medical School (United States); R. Pienaar, Children's Hospital Boston (United States) and Harvard Medical School (United States); D. A. Boas, M. A. Franceschini, J. Selb, Massachusetts General Hospital (United States) and Harvard Medical School (United States)

789204 Empirical factors affecting reconstruction of image-guided near infiared spectroscopy [7892-03]

M. A. Mastanduno, S. Jiang, Dartmouth College (United States); R. DiFlorio-Alexander, Dartmouth Medical School (United States); B. W. Pogue, Dartmouth College (United States); K. D. Paulsen, Dartmouth College (United States) and Dartmouth Medical School (United States)

789206 Spectrally-resolved imaging of dynamic turbid media [7892-05]

N. Hagen, N. Bedard, Rice Univ. (United States); A. Mazhar, S. Konecky, B. J. Tromberg, Univ. of California, Irvine (United States); T. S. Tkaczyk, Rice Univ. (United States)

\section{SESSION 2 MICROSCOPIC IMAGING}

789209 Integrated scanning laser ophthalmoscopy and optical coherence tomography for quantitative multimodal imaging of retinal degeneration and autofluorescence [7892-08] A. Issaei, L. Szczygiel, N. Hossein-Javaheri, M. Young, Simon Fraser Univ. (Canada); L. L. Molday, R. S. Molday, Univ. of British Columbia (Canada); M. V. Sarunic, Simon Fraser Univ. (Canada)

7892 OA Fiber-based combined optical coherence and multiphoton mic roscopy [7892-09] G. Liu, Z. Chen, Univ. of California, Irvine (United States)

7892 OB Combined OCTand CARS using a single ultrashort pulse Ti:Sapphire laser [7892-10] C. Hoffmann, Leibniz Univ. Hannover (Germany); B. Hofer, A. Unterhuber, B. Poăvzay, Medical Univ. Vienna (Austria) and Cardiff Univ. (United Kingdom); U. Morgner, Leibniz Univ. Hannover (Germany) and Laser Zentrum Hannover e.V. (Germany); W. Drexler, Medical Univ. Vienna (Austria) and Cardiff Univ. (United Kingdom) 
7892 OD Spectral a priori to spatial a posteriori in continuous-wave image reconstruction in near-infrared optical tomography [7892-12]

G. XU, D. Piao, Oklahoma State Univ. (United States); H. Dehghani, The Univ. of Birmingham (United Kingdom)

7892 OF Fully parallel adaptive finite element simulation using the simplified spherical hamonics approximations for frequency-domain fluorescence-enhanced optical imaging [7892-14] Y. Lu, B. Zhu, The Univ. of Texas Health Science Ctr. at Houston (United States); H. Shen, Virginia Polytechnic Institute and State Univ. (United States); J. C. Rasmussen, The Univ. of Texas Health Science Ctr. at Houston (United States); G. Wang, Virginia Polytechnic Institute and State Univ. (United States); E. M. Sevick-Muraca, The Univ. of Texas Health Science Ctr. at Houston (United States)

7892 OG Three dimensional time reversal optical tomography [7892-15]

B. Wu, W. Cai, M. Alrubaiee, The City College of The City Univ. of New York (United States); M. XU, Fairfield Univ. (United States); S. K. Gayen, The City College of The City Univ. of New York (United States)

7892 Ol In vivo reconstruction of NIR RRETusing full-field time resolved optical tomography [7892-17] V. Venugopal, J. Chen, Rensselaer Polytechnic Institute (United States); M. Barroso, Albany Medical College (United States); X. Intes, Rensselaer Polytechnic Institute (United States)

7892 0J Potentialities of a new bimodal Xray/ fluorescence tomograph within a cyindrical geometry for pre-clinical studies [7892-18]

A. Koenig, A. Planat-Chrétien, J.-G. Coutard, L. Hervé, M. Brambilla, CEA, LETI-MINATEC (France); V. Josserand, J.-L. Coll, Institut Albert Bonniot (France); J. Dinten, CEA, LETI-MINATEC (France)

7892 OK Concurrent magnetic resonance and diffuse luminescence imaging for hypoxic tumor charactenization [7892-19]

M. Seetamraju, X. Zhang, Radiation Monitoring Devices, Inc. (United States); S. Davis, Dartmouth College (United States); R. Gurjar, R. Myers, Radiation Monitoring Devices, Inc. (United States); B. W. Pogue, Dartmouth College (United States); G. Entine, Radiation Monitoring Devices, Inc. (United States)

$7892 \mathrm{OL}$ Tumor characterization by chromophore concentrations in small animals using a hybrid MRJ-DOTsystem [7892-20]

M. Hsing, Y. Lin, Univ. of California, Irvine (United States); M. B. Unlu, Bogazici Univ. (Turkey); O. Nalcioglu, G. Gulsen, Univ. of California, Irvine (United States)

7892 OM MRI-guided fluorescence tomography of PPIX in the breast a case study [7892-21] S. C. Davis, M. A. Mastanduno, B. W. Pogue, K. D. Paulsen, Dartmouth College (United States) 
7892 ON Feasibility of detecting mineral content in turbid medium using stimulated Raman photoacoustic imaging [7892-22]

R. Arora, G. I. Petrov, Univ. of Wisconsin-Milwaukee (United States); H. F. Zhang, Northwestern Univ. (United States); V. V. Yakovlev, Univ. of Wisconsin-Milwaukee (United States)

789200 Image contrast in fluorescence and magnetic resonance images for glioblastoma detection [7892-23]

K. S. Samkoe, S. L. Gibbs-Strauss, H. H. Yang, Dartmouth College (United States);

S. K. Hekmatyar, Dartmouth Medical School (United States); P. J. Hoopes, J. A. O'Hara, Dartmouth College (United States) and Dartmouth Medical School (United States); R. A. Kauppinen, Dartmouth Medical School (United States); B. W. Pogue, Dartmouth College (United States) and Dartmouth Medical School (United States)

\section{POSTER SESSION}

7892 OP Different optical spectral characteristics in a necrotic transmissible venereal tumor and a cystic lesion in the same canine prostate obsened by triple-band trans-rectal optical tomography under trans-rectal ultrasound guidance [7892-24]

Z. Jiang, G. R. Holyoak, J. W. Ritchey, K. E. Bartels, K. Rock, C. L. Ownby, Oklahoma State Univ. (United States); G. Slobodov, The Univ. of Oklahoma Health Sciences Ctr. (United States);

C. F. Bunting, D. Piao, Oklahoma State Univ. (United States)

$78920 \mathrm{~A}$ An investigation on fluorescent-optical dual-mode tomography using time-resolved data [7892-25]

L. Zhang, W. Zhang, F. Gao, J. Li, H. Zhao, Tianjin Univ. (China)

7892 OR Particle velocity measurements with macroscopic fluorescence imaging in lymph tissue mimicking mic rofluidic phantoms [7892-26]

R. Hennessy, California Polytechnic State Univ. (United States); C. Koo, P. Ton, A. Han,

R. Righetti, K. C. Maitland, Texas A\&M Univ. (United States)

7892 OS Research on high-order approximation of radiative transfer equation for image reconstruction [7892-27]

W. Ma, F. Gao, L. Wu, X. Yi, P. Zhu, H. Zhao, Tianjin Univ. (China)

7892 OT Integrating optical system designed for multimodal analysis of pearls and its mother oyster to distinguish and appraise cultured pearls [7892-28]

M. J. Ju, S. J. Lee, Y. Kim, J. G. Shin, D. H. Kim, Gwangju Institute of Science and Technology (Korea, Republic of); H. Y. Kim, Korea Pearl Lab. (Korea, Republic of); D. S. Lee, B. H. Lee, Gwangju Institute of Science and Technology (Korea, Republic of)

7892 OV Studying skin penetration by NMR imaging [7892-30]

J. M. Burg, Univ. of Applied Sciences Giessen-Friedberg (Germany); M. Voelker, Philipps Univ. Marburg (Germany); P. Schlupp, T. Schmidts, U. Maeder, T. Bergmann, F. Runkel, Univ. of Applied Sciences Giessen-Friedberg (Germany); J. T. Heverhagen, Philipps Univ. Marburg (Germany); M. Fiebich, Univ. of Applied Sciences Giessen-Friedberg (Germany) 
7892 OW An algorithm to comect 2D near-infiared fluorescence signals using 3D intravasc ular ultrasound architectural information [7892-31]

G. Mallas, Northeastern Univ. (United States) and Massachusetts General Hospital (United States); D. H. Brooks, Northeastern Univ. (United States); A. Rosenthal, Technische Univ. München (Germany); C. Vinegoni, M. A. Calfon, Massachusetts General Hospital (United States); R. N. Razansky, Technische Univ. München (Germany); F. A. Jaffer, Massachusetts General Hospital (United States); V. Ntziachristos, Technische Univ. München (Germany)

7892 OY A hybrid positron and OCTintraoperative probe for ovarian cancer detection and characterization [7892-36]

Y. Yang, N. C. Biswal, T. Wang, P. Kumavor, Univ. of Connecticut (United States);

M. Karimeddini, M. Sanders, M. Brewer, Univ. of Connecticut Health Ctr. (United States);

Q. Zhu, Univ. of Connecticut (United States)

$78920 Z$ In vivo tumor characterization using both MR and optical contrast agents with a hybrid MRJ-DOTsystem [7892-37]

Y. Lin, M. Ghijsen, D. Thayer, O. Nalcioglu, G. Gulsen, Univ. of California, Irvine (United States)

789210 In vivo comparison of kinetics of saline and ICG for the detection of nomal and tumor tissue using NIR diffuse optical technique [7892-38]

N. Liu, O. Nalcioglu, G. Gulsen, Univ. of California, Irvine (United States)

789211 Acquisition and reconstruction of Raman and fluorescence signals for rat leg imaging [7892-39]

J.-L. Demers, B. Pogue, F. Leblond, Dartmouth College (United States); F. Esmonde-White, P. Okagbare, M. Morris, Univ. of Michigan (United States)

789212 Development of a hybrid MRI and fluorescence tomography system for small animal imaging [7892-40]

M. T. Ghijsen, Y. Lin, O. Nalcioglu, G. Gulsen, Univ. of California, Irvine (United States)

789213 A hybrid approach combining microCTand fluorescence tomography: imaging workflow and system of coordinate registration [7892-41]

R. Holt, F. El-Ghussein, K. M. Tichaver, F. Leblond, B. W. Pogue, Dartmouth College (United States)

Author Index 


\title{
Conference Committee
}

\author{
Symposium Chairs
}

James G. Fujimoto, Massachusetts Institute of Technology (United States)

R. Rox Anderson, Massachusetts General Hospital (United States)

Program Track Chairs

Tuan Vo-Dinh, Duke University (United States)

Anita Mahadevan-Jansen, Vanderbilt University (United States)

Conference Chairs

Fred S. Azar, Becton, Dickinson and Company (United States)

Xavier Intes, Rensselaer Polytechnic Institute (United States)

Program Committee

Nicholas Ayache, INRIA Sophia Antipolis - Méditerranée (France)

David A. Boas, Massachusetts General Hospital (United States)

Britton Chance, University of Pennsylvania (United States)

Yu Chen, University of Maryland, College Park (United States)

Sergio Fantini, Tufts University (United States)

Keyvan Farahani, National Cancer Institute (United States)

Gultekin Gulsen, University of California, Irvine (United States)

Dimitris N. Metaxas, Rutgers, The State University of New Jersey (United States)

Nassir Navab, Technische Universität München (Germany)

Tim Nielsen, Philips Research (Germany)

Vasilis Ntziachristos, Helmholtz Zentrum München GmbH (Germany)

Brian W. Pogue, Dartmouth Hitchcock Medical Center (United States)

Siavash Yazdanfar, GE Global Research (United States)

Arjun G. Yodh, University of Pennsylvania (United States)

\section{Session Chairs}

$1 \quad$ Functional Diffuse Optical Imaging

Qianqian Fang, Massachusetts General Hospital (United States)

Xavier Intes, Rensselaer Polytechnic Institute (United States) 
2 Microscopic Imaging

Xavier Intes, Rensselaer Polytechnic Institute (United States)

Yu Chen, University of Maryland, College Park (United States)

3 Imaging Algorithms

Xavier Intes, Rensselaer Polytechnic Institute (United States)

Venkataramanan Krishnaswamy, Dartmouth College (United States)

$4 \quad$ Preclinical Imaging

Xavier Intes, Rensselaer Polytechnic Institute (United States)

Gultekin Gulsen, University of California, Irvine (United States) 


\section{Introduction}

Data generated by novel imaging technologies such as optical tomography are complex to analyze, due to the inherent scattering of light through anatomical systems. Cross validation and direct comparison with established methods in other imaging modalities are especially challenging. There is critical need for new computational techniques to provide rapid, accurate and cost-effective means for quantification and characterization of such data, either independently or integrated with other modalities. These computational methods will enable faster acceptance of novel imaging modalities into viable clinical and/or pre-clinical systems. The applications are diverse and range from imaging at the cellular level to the whole body while incorporating molecular, functional and anatomical information. The conference objectives are to provide a forum (1) to review and share recent developments in novel multimodal imaging techniques, (2) to report development of novel computational methods, and (3) to bring together the optical imaging and image analysis communities. Topics include, but are not limited to:

- multimodal imaging integrating structural, molecular and functional information

- 2D, 3D, 4D, tomographic and/or multi-spectral imaging

- imaging analysis and/or image processing techniques applied to optical imaging (e.g. visualization, segmentation, registration)

- detection and diagnostic analysis techniques which may provide better quantitative and/or diagnostic insight into clinical and pre-clinical imaging (e.g. methods for quantitative measurements, computer-assisted diagnosis...)

- imaging analysis and/or image processing techniques used to combine optical imaging with other imaging modalities (e.g. MR, X-Ray, PET...)

- image analysis, computational methods and reconstruction approaches which may help bring optical imaging into the clinic (visual rendering of complex data set, novel algorithms for assisted optical reconstruction, ...)

- Clinical evaluation of these new technologies (Physiological and functional interpretation of image data, visual perception and observer performances, validation of quantitative assessment of optical signatures in-vivo...).

Fred S. Azar Xavier Intes 
Downloaded From: https://www.spiedigitallibrary.org/conference-proceedings-of-spie on 26 Apr 2023

Terms of Use: https://www.spiedigitallibrary.org/terms-of-use 